With 5 plates

Printed in Great Britain

\title{
Electron Microscopic Observations on the Excretion of Cell-wall Material by Vibrio cholerae
}

\author{
By S. N. CHATTERJEE AND J. DAS \\ Department of Biophysics, School of Tropical Medicine, \\ Calcutta 12, India
}

(Accepted for publication 4 April 1967)

SUMMARY

Thin sections of Vibrio cholerae harvested during the logarithmic phase of growth in alkaline peptone water or in syncase medium have revealed an excretion process of the cell wall in the form of bulging out and pinching-off of portions. An identical phenomenon has also been revealed in cells harvested after a short period of incubation $(\mathrm{I} \cdot 5 \mathrm{hr})$ in glucose saline solution at $37^{\circ}$. Particles closely resembling the pinched-off cell-wall structures have been detected by metal shadowing and negative staining techniques in the bacteriafree filtrates of the log phase cultures (in both media) and the glucose saline incubation medium. These particles are in the range 400-1 $100 \AA$ in size with a maximum frequency in the range $600-800 \AA$. No similar cell-wall changes have been detected in vibrios harvested from the stationary phase of growth in any of the culture media, nor in vibrios undergoing plasmolysis. Turbidimetric tests revealed no significant lysis of the vibrios when harvested during the logarithmic growth phase and incubated for several hours in saline or in Kellenberger buffer as compared to the lysis detected in distilled water. It is suggested that the cell-wall process described represents an excretory mechanism of $V$. cholerae, and the nature of the products released by the young vibrios and their probable relation with cholera toxin is discussed.

\section{INTRODUCTION}

Vibrio cholerae, a highly pathogenic Gram-negative organism, has been extensively studied from the bacteriological, immunological, pathological and therapeutic points of view (Pollitzer, 1959; Proc. Cholera Res. Symp. 1965). Unfortunately the pathogenesis of the disease cholera still remains ill understood, although it has generally been supposed that some toxins or choleragenic products, which are always associated with the cholera vibrios, initiate the disease. It has been reported (Gallut, I954) that the toxins are released when the cholera vibrios are incubated in glucose saline medium at $37^{\circ}$ for $4-6 \mathrm{hr}$. Recent investigations (Burrows, 1965; De, Ghose \& Sen, 1960; De, Ghose \& Chandra, 1962; Finkelstein, Norris \& Dutta, 1964; Finkelstein, 1965) have indicated that the choleragenic products are likely to be liberated by the young vibrios presumably by a secretion process; however conclusive evidence for this has not yet been obtained.

In course of our investigation of the ultrastructure of Vibrio cholerae, part of which has been published earlier (Das \& Chatterjee, 1966), attention was drawn to an interesting differentiation in the cell-wall structure of the young vibrios. The present report is devoted to this aspect of $V$. cholerae and describes structures which suggest 
a mechanism for the excretion of substances by the vibrios. A preliminary report of our observations has already been published elsewhere (Chatterjee \& Das, 1966).

\section{METHODS}

Strains. Vibrio cholerae INABA 430, INABA C84 (both obtained from the Department of Bacteriology of this Institution) and OGAWA I54 (obtained through the courtesy of Dr S. Mukherjee, Indian Institute of Experimental Medicine, Calcutta) were used throughout this investigation. The organisms were maintained by fortnightly subcultures on nutrient agar slopes.

Media. The media used for the cultivation of the vibrios included the following: (i) nutrient agar; (ii) peptone water containing $\mathrm{I} \%$ (w/v) bacto-peptone (Difco) and $0.5 \%$ sodium chloride in distilled water $(\mathrm{pH} 8.0)$; and (iii) syncase medium (Finkelstein, Atthasampunna, Chulasamaya \& Charunmethee, 1966) containing $5 \mathrm{~g}$. $\mathrm{Na}_{2} \mathrm{HPO}_{4}, 5$ g. $\mathrm{K}_{2} \mathrm{HPO}_{4}$, 5 g. sucrose, $\mathrm{I} \cdot \mathrm{I} 8 \mathrm{~g}$. $\mathrm{NH}_{4} \mathrm{Cl}, 0.089 \mathrm{~g} . \mathrm{MgCl}_{2} \cdot 6 \mathrm{H}_{2} \mathrm{O}, 0.004 \mathrm{~g}$. $\mathrm{MnCl}_{2} \cdot 4 \mathrm{H}_{2} \mathrm{O}, 0.005 \mathrm{~g}$. $\mathrm{FeCl}_{3} \cdot 6 \mathrm{H}_{2} \mathrm{O}$ and $\mathrm{IO} \mathrm{g}$. Casamino acids (Difco) dissolved in $\mathrm{I} 1$. distilled water.

Inoculum. Vibrios were washed from the surface of nutrient agar slopes and suspended in saline solution $(0.85 \%)$, and $\mathrm{I} \mathrm{ml}$. amounts of this suspension were then spread over the surface of nutrient agar plates and incubated at $37^{\circ}$. Vibrios from an $18 \mathrm{hr}$ growth on the nutrient agar were resuspended in suitable volumes of $0.85 \%$ saline, and after one or two washes in the same solution, adjusted so that the optical density of the final suspension was $1 \cdot 0$, then $0.1 \mathrm{ml}$. of this final suspension was used as the inoculum for $20 \mathrm{ml}$. peptone water or syncase medium distributed in Erlenmeyer flasks of $100 \mathrm{ml}$. capacity (De et al. 1962; Finkelstein, 1965). In some cases $20 \mathrm{ml}$. of peptone water medium were seeded with a heavy loopful from an agar culture and $\mathrm{I} \mathrm{ml}$. of $\mathrm{I} 8 \mathrm{hr}$ growth in this medium at $37^{\circ}$ was used to inoculate the final growth medium.

Growth estimation. The growth of Vibrio cholerae in peptone water or syncase medium at $37^{\circ}$ was estimated by measuring the optical density at $650 \mathrm{~m} \mu$ with a photoelectric colorimeter.

Incubation in glucose saline. Vibrios harvested from $18 \mathrm{hr}$ growth on nutrient agar were washed in $0.85 \%$ saline and suspended in suitable volumes of glucose saline ( $\mathrm{NaCl} 0.85 \mathrm{~g}$., glucose 0.5 g., distilled water $100 \mathrm{ml}$.) (Bernard \& Gallut, 1943; Gallut, 1954) distributed in Erlenmeyer flasks (100 ml. capacity) in volumes of $20 \mathrm{ml}$., the initial optical density of the suspension thus being adjusted in the range $0 \cdot 8-1 \cdot 0$. The suspension was then incubated at $37^{\circ}$ and its $\mathrm{pH}$ was recorded at regular intervals with an electronic $\mathrm{pH}$ meter. Incubation was continued for a maximum period of $24 \mathrm{hr}$.

Membrane filtration. The membrane filters used were type B-6, Bac-T-flex (Carl Schleicher and Schuell Co., Keene, New Hampshire, U.S.A.) obtained through the courtesy of Dr E. T. Bolton, Carnegie Institute, Washington, U.S.A. Cultures in the logarithmic growth phase or bacterial suspensions in glucose saline after different periods of incubation were filtered through these membranes; the filtrates in all cases were found free of bacteria when tested by electron microscopy. The non-inoculated culture media (controls) were also similarly filtered and the filtrates examined by electron microscopy. 
Metal shadowing and negative staining. For metal shadowing, a small drop of the bacteria-free filtrate obtained from a log-phase culture or from the glucose saline medium was deposited on a carbon-coated copper grid and the excess liquid was withdrawn a few seconds later. The preparation was then washed quickly in distilled water, dried and shadowed obliquely with chromium. For negative staining I \% (w/v) uranyl acetate solution in distilled water was deposited immediately after the residue on the carbon substrate was washed in distilled water. The excess uranyl acetate was withdrawn a few seconds later and the preparation was dried (Huxley \& Zubay, 1960).

Thin sectioning. The cells were harvested after the desired periods of incubation in the growth media or in a glucose saline solution by centrifugation and fixed in $1 \%$ $(\mathrm{w} / \mathrm{v})$ osmium tetroxide solution in Kellenberger buffer $(\mathrm{pH} 6 \cdot \mathrm{I})$ for $\mathrm{I6}-20 \mathrm{hr}$ at room temperature (Kellenberger, Ryter \& Séchaud, 1958). The fixed cells were washed in $0.5 \%$ uranyl acetate in the same buffer for about $2 \mathrm{hr}$. The washed cells were placed between layers of agar, dehydrated in graded ethanol and embedded in a methacrylate mixture (methyl:butyl = 2:3) or in Epon (Luft, I96I). Methacrylate mixture was prepolymerized (Borysko \& Sapranauskas, 1954) to reduce the polymerization damage and the corresponding sections after being stained were overlaid with a very thin film of carbon (Watson, 1957) to reduce the sublimation artifact. Thin sections were cut with glass knives on a Porter Blum ultra-microtome. Sections were stained with uranyl acetate and/or lead citrate (Reynolds, 1963) or with potassium permanganate (Lawn, 1960).

Electron microscopy. All electron micrographs were taken by a Hitachi HS-6 electron microscope at instrumental magnifications ranging from $\times 6000$ to 15,000 Measurements were made from the enlarged prints by a micrometer eyepiece (accuracy O. I mm).

Turbidimetric test of lysis. Vibrio cholerae were harvested from $18 \mathrm{hr}$ growth on agar surface or 3 to $5 \mathrm{hr}$ subcultures in peptone water or syncase medium (log phase), washed in $0.85 \%$ saline, resuspended in (i) distilled water, (ii) saline $(0.85 \%)$, or (iii) Kellenberger buffer ( $\mathrm{pH} 6 \cdot 1$ ) and incubated at $37^{\circ}$ for different periods. To test whether the vibrios were undergoing lysis the optical density of the suspensions was measured by a photoelectric colorimeter after different periods of incubation. In some cases turbidimetric tests were checked by electron microscopic examination of the whole cells and satisfactory agreement was obtained.

\section{RESULTS}

In an earlier publication (Das \& Chatterjee, 1966) the ultrastructure of the flagellum, attachment of the flagellum to the cell, the cell wall and the plasma membrane of Vibrio cholerae has been described. The fine structures of these organelles in $V$. cholerae were found, in general, to be similar to the corresponding organelles of $V$. metchnikovii (Glauert, Kerridge \& Horne, 1963).

Ultrastructure of the protoplasm. The considerably electron-transparent central region in Vibrio cholerae represents its nucleus. The nuclear zone seems to be crossed over at places by bridges of cytoplasmic materials (Pl. 2, fig. 3; Pl. 3, fig. 6; Pl. 4, fig. II). The nucleoplasm contained a random network of fibrils or strands of dimension varying between 20 and $50 \AA$ (P1. I, fig. 2; P1. 2, fig. 5). These fibrils were stained by the uranyl acetate and were presumably the chromatin strands and will be thus 
denoted, although no definite evidence of their chemical nature has yet been obtained. At places the strands were observed to cross the nuclear zone transversely and merge into the peripheral cytoplasmic material (arrow, P1. 2, fig. 5).

Numerous small granules were found in the bacterial cytoplasm. The granules mostly had a dimension between 100 and $200 \AA$ and were presumably ribosomes. Although dense populations of these granules frequently resisted elucidation as to the nature of their disposition in the bacterial cytoplasm, evidence was obtained which indicated that the granules were frequently interconnected by fibrillar structures prevalent in the cytoplasm (Pl. 2, fig. 4; Pl. 3, figs 8, 9). Although the typical membrane structures could not be resolved by the electron microscope used, the manner in which the cytoplasmic fibrillar structures were found to be connected with the plasma membrane in many pictures (P1. 2, fig. 4; Pl. 3, fig. I0; arrowed) suggests that some of the fibrillar structures possibly represent the infolded plasma membrane. Many of the granules were prominently stained by potassium permanganate ( $\mathrm{Pl} .3$, figs 6, 8-10).

Excretion of cell-wall material. Vibrio cholerae harvested from the logarithmic growth phase was found to exhibit some interesting morphological features. The cell wall, in places, was found to bulge out, and different stages of the bulging were recorded (Pl. 2, figs 3, 5; Pl. 3, figs 6, 10 ; Pl. 4, figs $\mathrm{II}, 13$ ) in this investigation. When the wall region bulged out considerably, its neck became increasingly constricted (Pl. 2, fig. 3 ; Pl. 4, figs II, 13) and the membrane sac so formed appeared to get pinched off the bacterial surface and was presumably released into the medium. It was often observed that the bulged-out cell-wall region was associated with some small granules at the surface (Pl. 2, fig. 3; Pl. 3, figs 6, 7, 10). In some cases distinct granules were not observed, but instead a greater electron density was imparted to portions of the bulged-out membrane. This was possibly due to the coalition of the individual small granules. The maximum dimension of the bulged-out membrane region, as measured from thin sections, was usually less than $1000 \AA$ and in very few cases between 1000 and $2000 \AA$. Identical pictures were obtained both in methacrylate- and Epon-embedded cells of young cholera vibrios. It is of interest to note that no similar bulging process of the cell wall was detected in vibrios harvested while in the stationary phase of growth (Pl. I, figs I, 2). However, particles resembling pinched-off membrane sacs and apparently lying isolated in the neighbourhood of the bacterial cells have often been revealed in thin sections (Pl. I, figs I, 2). Thin sections of many bacteria caught in the dividing stage exhibited the phenomenon of bulging out of the cell-wall membrane regions ( $\mathrm{Pl} .3$, figs 6,7 ). Potassium permanganate staining revealed clearly the presence of granules in association with the bulged-out cell-wall membrane region (Pl. 3, figs 7,10 ). The nature of these granules in relation to those found in the bacterial protoplasm remains unknown.

Particles resembling the pinched-off membrane sacs observed in thin sections were also detected in the bacteria-free filtrates of log-phase cultures (P1. 5, figs I5, I6). The dimensions of these particles were found to vary between 400 and IIOO $\AA$ (Fig. I). Identical particles have been observed when the bacteria were grown in peptone water medium or in Finkelstein's syncase medium (Finkelstein et al. 1964), although electron microscopic sampling indicated the greater prevalence of these particles in the latter medium than in the former. Filtrates of uninoculated culture medium did not exhibit the presence of any similar particulate structure. 


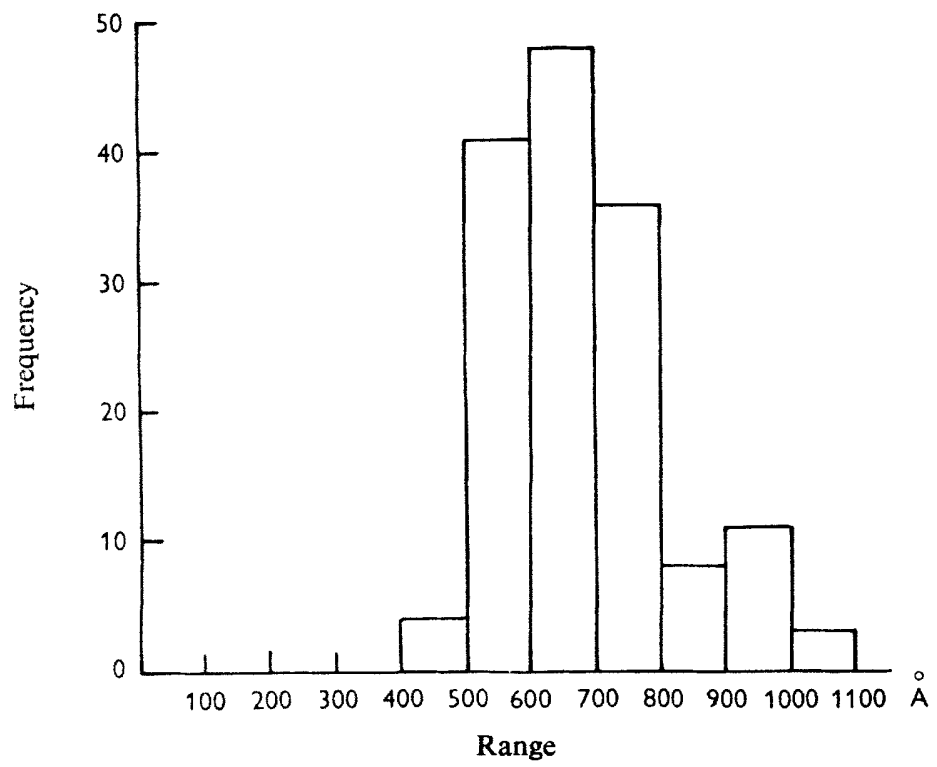

Fig. I. Histogram showing the distribution of the diameter of particles isolated from the log-phase peptone-water-culture medium.

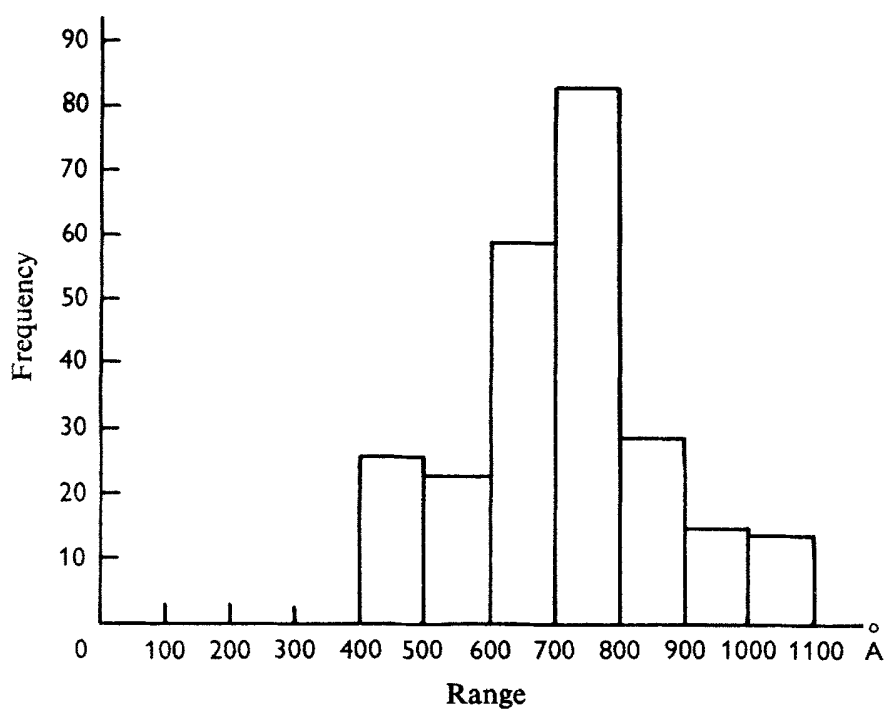

Fig. 2. Histogram showing the distribution of the diameter of particles isolated from glucose-saline filtrate.

When the vibrios harvested from $18 \mathrm{hr}$ growth on agar were incubated in glucose saline and filtered after the $\mathrm{pH}$ had dropped to about 5.4 and all the glucose had been used up, numerous particles again resembling the membrane sacs observed in thin section were observed in the bacteria-free filtrate (PI. 5, fig. 14). The size distribution of the particles obtained from glucose saline filtrate is shown in Fig. 2. At this stage of incubation, a considerable change in the bacterial morphology has taken place, the 
details of which will be described in a separate paper. But even at the initial stages of incubation (within $\mathrm{I} .5 \mathrm{hr}$ ), when metal shadowing and thin sectioning techniques revealed no significant change in the ultrastructural features of the bacterial protoplasm as compared with the resting phase (Pl. I, figs I, 2), numerous such particles were detected. Thin section of the vibrios at such an early stage of incubation revealed the bulging-out and pinching-off process of the cell wall (Pl. 4, fig. I3) as in the case of log-phase vibrios.

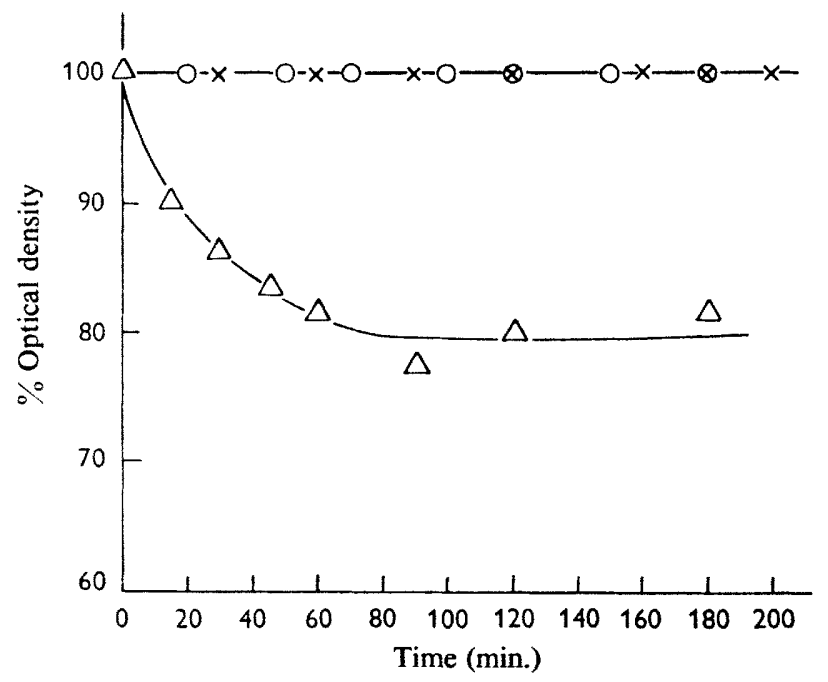

Fig. 3. Optical density against time of incubation of the vibrios at $37^{\circ}$ in (i) normal saline $-\mathrm{O}-$;

(ii) Kellenberger's buffer $-x-$ and (iii) distilled water $-\triangle-$.

When vibrios were incubated in Kellenberger buffer or in normal saline at $37^{\circ}$, no significant fall in the turbidity of the suspension was recorded, whereas in distilled water a significant fall in turbidity was noted after as little as $\mathbf{2 0} \mathrm{min}$. incubation period, indicating that the cells were undergoing lysis (Fig. 3). At the initial stage of plasmolysis, the vibrio protoplasm was found to retract from the cell wall (P1. 4, fig. I2) but the structure of the cell-wall membrane remained smooth.

\section{DISCUSSION}

Excretion of cell-wall material. Thin sectioning of the young cholera vibrios has revealed the process of bulging out and pinching off of the cell wall in the form of approximately spherical sacs. This phenomenon of the vibrio cell wall has been seen in methacrylate- and in Epon-embedded specimens irrespective of the electron stain used. Exactly similar observations have been made when the vibrios were harvested from 16 to $18 \mathrm{hr}$ growth on agar and incubated in glucose saline solution. Neither in thin sections nor in metal-shadowed preparations of cells bearing extrusions could any significant change in the protoplasmic structure be discerned as compared with resting phase cells. Vibrios harvested from the stationary phase of growth do not show a similar turnover of the cell wall. Further, particles resembling pinched-off membrane sacs have been detected in thin sections in bacteria-free filtrates of log-phase cultures, in alkaline peptone water, Finkelstein syncase media, and in glucose saline incubation medium. On the other hand, ultra-thin section of the vibrios undergoing plasmolysis 
do not show any similar membrane turnover process. In all cases where cell-wall excretion has been noted in the vibrios, no evidence has been obtained of any bulging out of the protoplasm and the plasma membrane has remained undamaged. When young vibrios were suspended in saline solution or in Kellenberger buffer only (without the osmic acid) and incubated at $37^{\circ}$, no significant fall in the turbidity resulted. These observations seem to rule out the possibility of any plasmolysis occurring during the preparation of the vibrios for electron microscopy. It is therefore suggested that the cell-wall changes described do represent a mechanism of excretion of cell-wall material by young cholera vibrios.

Micro-anatomical studies of secretory and other tissues have produced considerable evidence of membrane activity at the surface of certain cells (Bennett, 1956). It is by virtue of the plasticity of the cellular membrane that substances which cannot diffuse through it may be incorporated by, for example, pinocytosis (Lewis, I93I; Palade, 1953) or may be excreted from the cells. Although there may exist several mechanisms for the excretion or secretion of cellular products (Kurosumi, 1961, 1962), the mechanism of reversed pinocytosis (Palade, 1959, 1960, 1961; Lever \& Peterson, 1960; Lever, 1962; Farquhar, 1961 $a, b$ ) has been observed in many cells. However, a prerequisite of this method of excretion is the inclusion of secretory substances by smooth membranes within the cells, in other words the substances secreted are in some way enclosed in an intracellular vesicle, which then migrates towards, adheres to, and finally communicates with the cell membrane (Lever, 1962). The mechanism of release of the sac-like structures by Vibrio cholerae observed in this investigation is clearly different. However a simple pinching off of part of a cell may constitute a method of secretion (Aberchrombie, Hickman \& Johnson, 1957). The extrusion of the so-called colloid bodies from the thyroid cell to the vesicle possibly occurs by the budding off of apical cytoplasm (Lever, 1961). A similar mechanism has been observed in the secretory process of the rabbit apocrine sweat glands (Kurosumi, 1962). This process has some similarity with the excretory activity of $V$. cholerae, as postulated in this study, but in detailed analysis many differences may again be detected, some of which could be due to the differences between the anatomy of a bacterial and a mammalian cell. It is only of interest to note here that a similar mechanism has also been found in the escape of certain viruses from cells (Epstein, 1962).

The excretion product. From the evidence presented above it appears that the secretion product of the vibrios possibly contains some substances of unknown chemical nature within an apparently closed sac bounded by the cell-wall membrane. It is likely that the enzymes or other chemicals of the vibrios normally located in between the cell-wall membrane and the plasma membrane are excreted in this process and are contained in the considerably electron-transparent cores, as seen in thin sections, of the spherical excretion bodies. Thin sectioning has provided some evidence of the presence of small granules in the excreted vesicles. Metal shadowing or uranyl staining has, however, failed to reveal the presence of granules. This is consistent, however, provided it is assumed that the granules are not at the outer surface of these bodies, since metal shadowing can reveal the surface details only and the negative staining with uranyl acetate or phosphotungstate is of no help in elucidating the inner structures in the case of bodies which are not penetrated by the stain. However, until more evidence is available, the presence of the granules within the excretion products, their nature and their site of formation in the bacterial cell remain to a great extent undetermined. 
Probable relation of the excretion product with cholera toxin. It has been reported that the Vibrio cholerae cells incubated in glucose saline solution at $37^{\circ}$ produce toxins which are lethal to mice when injected intraperitoneally (Gallut, 1954). The mode of release of the toxins by the vibrios was unknown. These toxins were detected in the bacteria-free filtrate and ultrafiltration studies indicated that they consisted of two components, one glucolipidic in nature and between 800 and $1000 \AA$ in size while the other was of unknown chemical nature and about $40 \AA$ in size (Gallut \& Grabar, 1945). These sizes thus compare well with the dimensions (400-1100 $\AA$ ) of spherical particles we have found being released by the living young vibrios while incubated under identical conditions in glucose saline solution or in culture media (peptone water or syncase medium). However, Gallut and his associates did not conceive of these toxins as being secreted by the living vibrios and the evidence put forward by them was not sufficient to decide whether these were exo- or endo-toxins. On the other hand we have not yet been able to isolate these particles, free of the higher and lower molecular weight substances that might be present, so as to determine whether they are toxic. However, it is likely that the particles we have observed being released by the vibrios correspond to the cholera toxin studied by Gallut since identical particles (identical in dimension at least) have been found under identical experimental conditions. Further similarities may be drawn since according to Gallut (1965) the major part of the choleratoxin is located in the cell wall and the residual toxicity of the vibrio protoplast is relatively weak. Thin sectioning has shown definitely in this study the presence of cell-wall material in the excreted particles.

Recent studies have indicated, as summarized by Burrows (1965), that the vibrios secrete the toxin during their early phase of growth and that it is unlikely that the toxins are leached out of the cells since they are not dialysable. Thus De et al. (I960, 1962) reported the liberation of cholera exo-toxin in young cultures of vibrios in peptone water medium, and Finkelstein et al. (1964) found the presence of choleragenic products, as tested by the infant rabbit technique (Dutta \& Habbu, 1955), in young cultures of the vibrios in brain heart infusion broth and also in the syncase medium of Finkelstein et al. (1966). Finkelstein et al. (1964) further observed that the cholaragenic product could be separated by dialysis into two fractions-Procholeragen A and Procholeragen B, as they termed them, of which the factor A is non-dialysable and the factor $B$ is dialysable. These results thus lend support to the present electron microscopic evidences in so far as the excretory activity of the young cholera vibrios and the presence of a high molecular weight component in the excretion product are concerned. It has to be admitted again that there is yet no clear relationship between the excretion product observed in this investigation and the choleragenic product described by Finkelstein et al. (1964). It is of interest to note in this respect that the evidence obtained so far has indicated the presence of polysaccharide and lipid components in the choleragenic product (Burrows, I95I; Dutta \& Oza, I963; Bhatia, Kaur, Bhatia \& Shrivastava, 1966). Cell walls of Gram-negative bacteria are known to contain lipopolysaccharide. Knox, Vesk \& Work (1966) have described the morphology of the excretion of lipolysaccharide by a lysine-requiring mutant strain of Escherichia coli. This is somewhat similar to the presently observed morphology of the excretion of cell-wall materal by $V$. cholerae, although the conditions of excretion in the two cases are different. 
The authors are indebted to Dr J. B. Chatterjea, Director, School of Tropical Medicine, Calcutta, for his kind interest in the work. This investigation was supported by a research grant from the Indian Council of Medical Research, Government of India. One of us (J.D.) is indebted to the I.C.M.R. for the award of a Research Assistantship.

\section{REFERENCES}

Aberchrombie, N., Hickman, C. J. \& Johnson, M. L. (1957). A Dictionary of Biology. Aylesbury: Hunt, Barnard and Co. Ltd.

BENNETT, H. S. (1956). The concepts of membrane flow and membrane vesiculation as mechanisms for active transport and ion pumping. J. biophys. biochem. Cytol. 2, Suppl., 99.

Bernard, P. N. \& Gallut, J. (I943). Sur une mode de préparation de la toxine cholérique. C. $r$. Séanc. Soc. Biol. 137, Io.

Bhatia, R, Y. P., Kaur, J., Bhatia, A. L. \& Shrivastava, J. B. (1966). Choleragenic property of lipopolysaccharide fraction from Vibrio cholerae Inaba. Indian J. med. Res. 54, 323.

BorysKo, E. \& SAPranausKas, P. (1954). A new technique for comparative phase contrast and electron microscope studies of cells grown in tissue culture with an evaluation of the technique by means of time lapse cinemicrographs. Bull. Johns Hopkins Hosp. 95, 68.

Burrows, W. (1951). Endotoxins. A. Rev. Microbiol. 5, 181.

Burrows, W. (1965). Cholera vibrio toxicities. Proc. Cholera Res. Symp. Honolulu, p. I 20.

ChatterJee, S. N. \& DAS, J. (1966). Secretory activity of Vibrio cholerae as evidenced by electron microscopy. In Electron Microscopy. Ed. R. Uyeda, Vol. II, p. OO-259. Tokyo: Maruzen Co. Ltd.

Das, J. \& ChatterJeE, S. N. (1966). Electron microscopic studies on some ultrastructural aspects of Vibrio cholerae. Indian J. med. Res. 54, 330.

DE, S. N., Ghose, M. L. \& SEN, A. (1960). Activities of bacteria-free preparations from Vibrio cholerae. J. Path. Bact. 79, 373.

DE, S. N., Ghose, M. L. \& Chandra, J. (1962). Further observations on cholera enterotoxin. Trans. R. Soc. trop. Med. Hyg. 56, $24 \mathrm{I}$.

DutTA, N. K. \& HABBU, M. K. (1955). Experimental cholera in infant rabbits. A method for chemotherapeutic investigation. Br. J. Pharmacol. Chemother. 10, 153.

Dutra, N. K. \& OzA, N. B. (1963). The effect of gastro-intestinal enzymes on cholera toxin. Bull. Wld Hith Org. 28, 307.

Epstein, M. A. (1962). Functional aspects of the structure of some animal viruses. Br. med. Bull. 18, 183.

FARQUhAR, M. G. $(1961 a)$. Fine structure and function in capillaries of anterior pituitary gland. Angiology 12, 270.

Farquhar, M. G. (1961 b). Trans. N.Y. Acad. Sci. 23, 346. (Cited by Lever, 1962.)

Finkelstein, R. A., NorRis, H. T. \& Dutta, N. K. (1964). Pathogenesis of experimental cholera in infant rabbits. J. infect. Dis. I14, 203.

Finkelstein, R. A. (1965). Observations on the nature and mode of action of the choleragenic product(s) of cholera vibrios. Proc. Cholera Res. Symp. Honolulu, p. 264.

Finkelstein, R. A., Atthasampunna, P., Chulasamaya, M. \& Charunmethee, P. (I966). Pathogenesis of experimental cholera: biologic activities of purified procholeragen A. J. Immun. 96, 440.

Gallut, J. \& Grabar, P. (1945). Recherches immunochimiques sur de vibrion cholérique. III. Mise en évidence de deux constituants toxiques de nature différente dans la toxine cholérique. Annls Inst. Pasteur, Paris, 7r, 83.

Gallut, J. (1954). Contribution a l'étude de la toxine cholerique: Variation du pouvoir toxique de Vibrio cholerae (Ogawa) au cours de la maladie. Annls Inst. Pasteur, Paris, 86, 56I.

Gallut, J. (1965). Antigenic structure of vibrios. Proc. Cholera Res. Symp. Honolulu. p. 235.

GLAUERT, A. M., KeRRIDGE, D. \& HORNE, R. W. (1963). The fine structure and the mode of attachment of the sheathed flagellum of Vibrio metchnikovii. J. Cell Biol. 18, 327.

HuXLeY, H. E. \& ZUBAY, G. (1960). Electron microscope observations on the structure of particles from Escherichia coli. J. molec. Biol. 2, 10. 
Kellengerger, E., Ryter, A. \& SÉChAud, J. (1958). Electron microscope study of DNA plasms. J. biophys. biochem. Cytol. 4, 671.

Knox, K. N., Vesk, M. \& Work E. (1966). Relation between excreted lypolysaccharide complex and surface structures of a lysine-limited culture of Escherichia coli. J. Bact. 92, I 206.

Kurosumi, K. (1961). Electron microscopic analysis of the secretion mechanism. Int. Rev. Cytol. II, I.

KuRosumi, K. (1962). Some morphological aspects on the secretory activities of various glandular cells. In Electron Microscopy. Ed. by S. S. Breese. Vol. I, p. YY-I. New York and London: Academic Press.

LAWN, A. M. (1960). The use of potassium permanganate as an electron dense stain for sections of tissue embedded in epoxy resin. J. biophys. biochem. Cytol. 7, 197.

LeVer, J. D. \& Peterson, R. (1960). Trans. N.Y. Acad. Sci. 22, 504. (Cited by Lever, 1962.)

Lever, J. D. (1961). In Electron Microscopy in Anatomy. Ed. by J. D. Boyd, F. R. Johnson and J. D. Lever, p. 207. London: Arnold. (Cited by Lever, 1962.)

LeVER, J. D. (1962). Fine structural organisation in endocrine tissues. Br. med. Bull. 18, no. 3, 229.

Lewis, W. H. (1931). Pinocytosis. Bull. Johns Hopkins Hosp. 49, 17.

LuFT, J. H. (1961). Improvements in epoxy resin embedding methods. J. biophys. biochem. Cytol. 9 , 409.

MilloniG, G. (196I). A modified procedure for lead staining of thin sections. J. biophys. biochem. Cytol. Ir, 736.

PALAdE, G. E. (1953). Fine structure of blood capillaries. J. appl. Phys. 24, 1424.

PALADE, G. E. (1959). Functional modulations in cell structure. In Sub-cellular particles. Ed. by T. Hayashi, p. 264. New York: Ronald Press.

Palade, G. E. (1960). Transport in quanta across the endothelium of blood capillaries. Anat. Rec. I36, 254.

PAlAdE, G. E. (196I). In Electron Microscopy in Anatomy. Ed. by J. D. Boyd, F. R. Johnson and J. D. Lever, p. 176. London: Arnold. (Cited by Lever, 1962.)

Polurtzer, R. (1959). Cholera. Monograph Ser. W.H.O. No. 43.

Proceedings of the Cholera Research Symposium, Honolulu, 1965. Washington, U.S.A.: Dept Hlth, Education \& Welfare.

Reynolds, E. S. (1963). The use of lead citrate at high pH as an electron opaque stain in electron microscopy. J. Cell Biol. 17, 208.

Watson, M. L. (1957). Reduction of heating artifacts in thin sections examined in electron microscope. J. biophys. biochem. Cytol. 3, 1017.

\section{EXPLANATION OF PLATES}

\section{Plate 1}

Fig. I. Ultrathin section of $V$. cholerae harvested from the stationary phase of growth in peptone water medium; stained with lead. $\times 40,000$.

Fig. 2. V. cholerae cells harvested from the stationary phase of growth in Syncase medium; stained with lead. Dispersed chromatin strands (CS), 100-200 $\AA$ granules (G) and smooth cell wall (CW) and plasma membrane $(\mathrm{PM})$ shown. $\times 100,000$.

\section{Plate 2}

Fig. 3. V. cholerae from the logarithmic phase of growth in peptone water; stained with lead. Many cell-wall bulges can be seen. The sequence of the process is perhaps as indicated by the sequence of the letters A, B and C. Arrows indicate the association of granules with the bulged out cell-wall membrane. $\times 100,000$.

Fig. 4. Portion of a longitudinal section of $V$. cholerae stained with lead. Arrows indicate the regions where some of the cytoplasmic fibrillar structures may have originated by an infolding of the plasma membrane. Many I00-200 \& granules (G) can be seen interconnected by fibrils. $\times$ I I0,000.

Fig. 5. V. cholerae harvested from logarithmic phase of growth in Syncase medium; uranyl acetate stained. Chromatin strands (CS) are distinct. Arrows show the merging of chromatin strands in the cytoplasm. Bulging of the cell wall is shown at A and B. $\times 93,000$. 

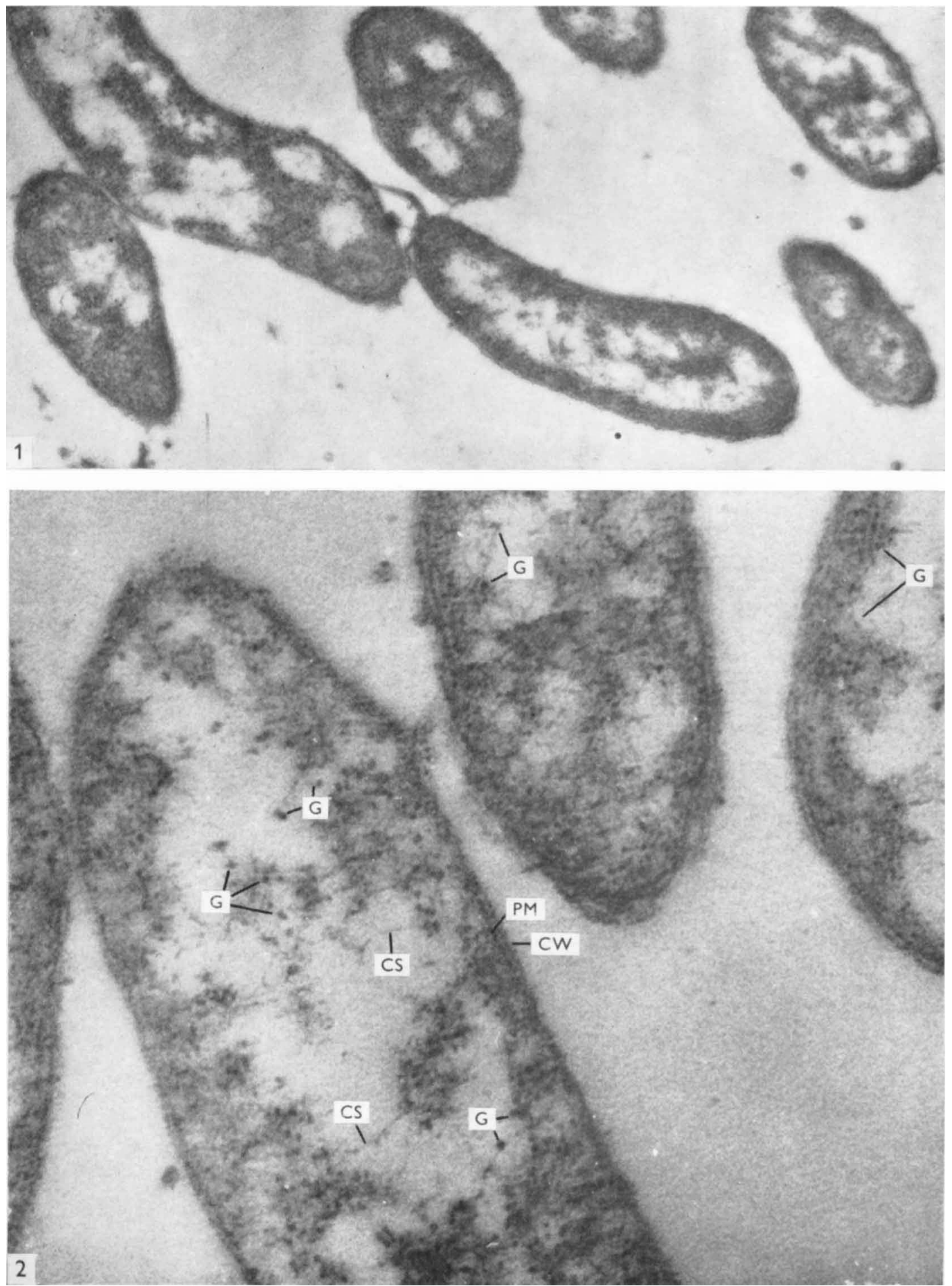
Journal of General Microbiology, Vol. 49, No. 1

Plate 2
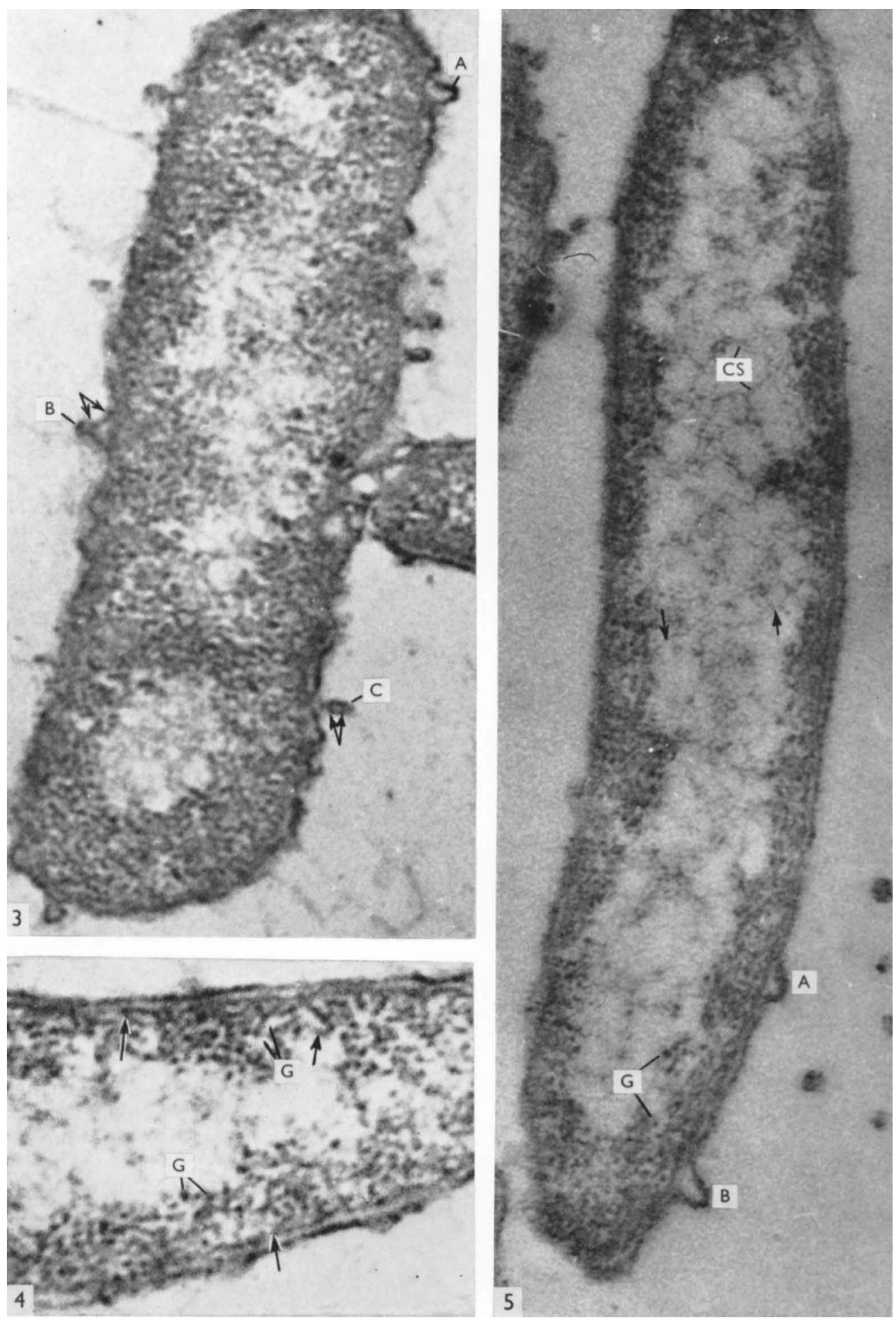

S. N. CHATTERJEE AND J. DAS 
Journal of General Microbiology, Vol. 49, No. 1

Plate 3

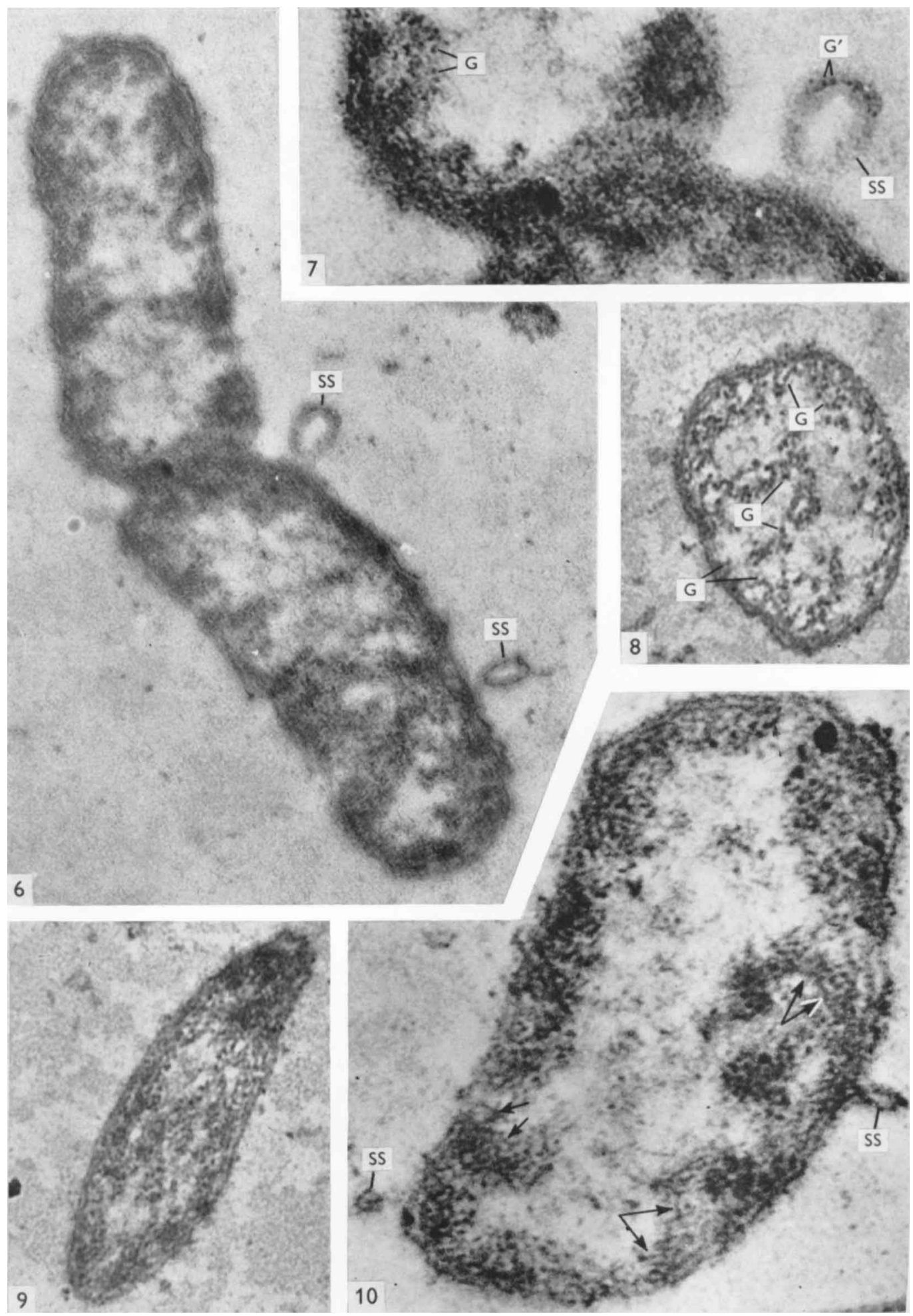

S. N. CHATTERJEE AND J. DAS 
Journal of General Microbiology, Vol. 49, No. 1

Plate 4
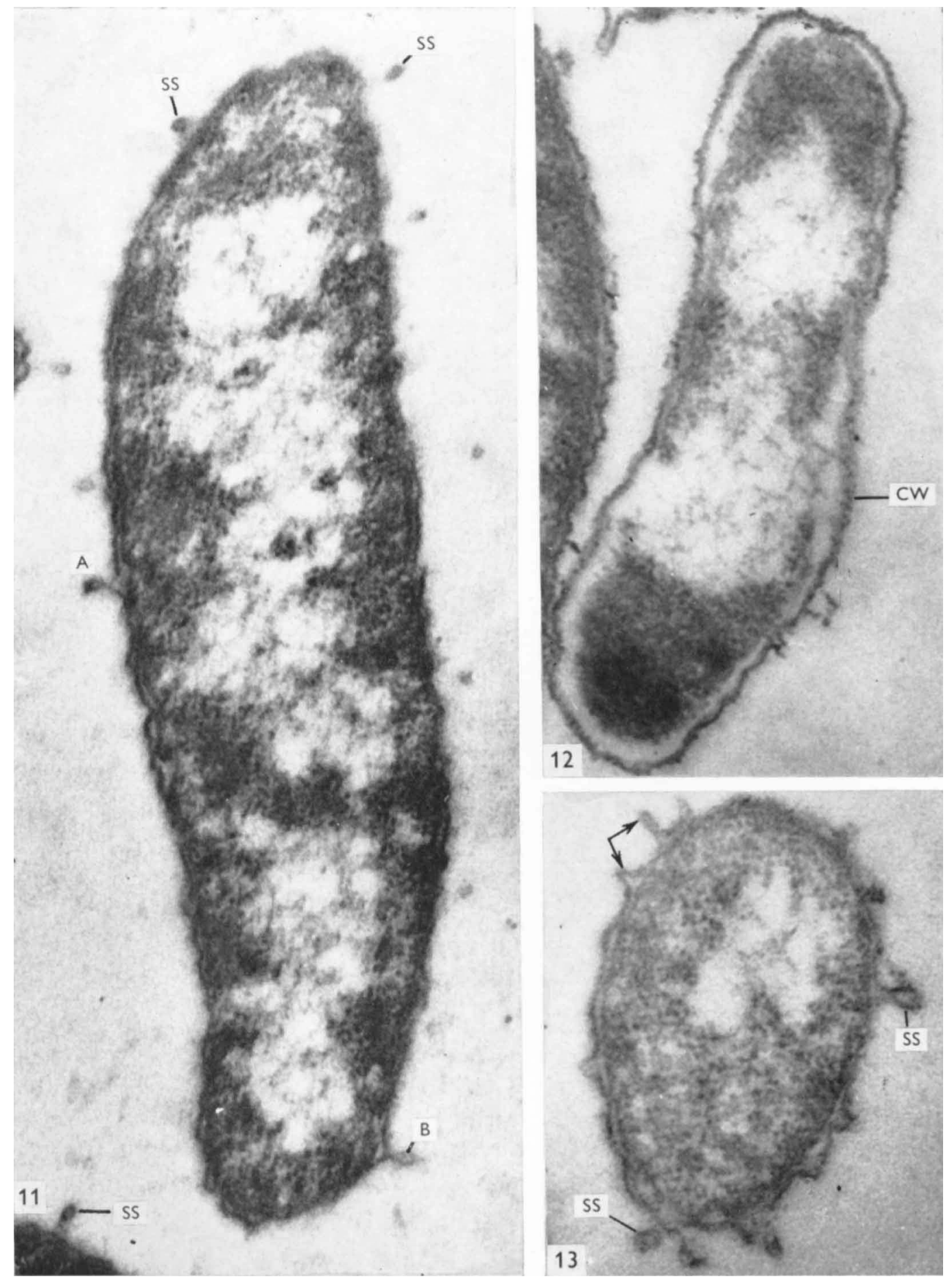

S. N. CHATTERJEE AND J. DAS 

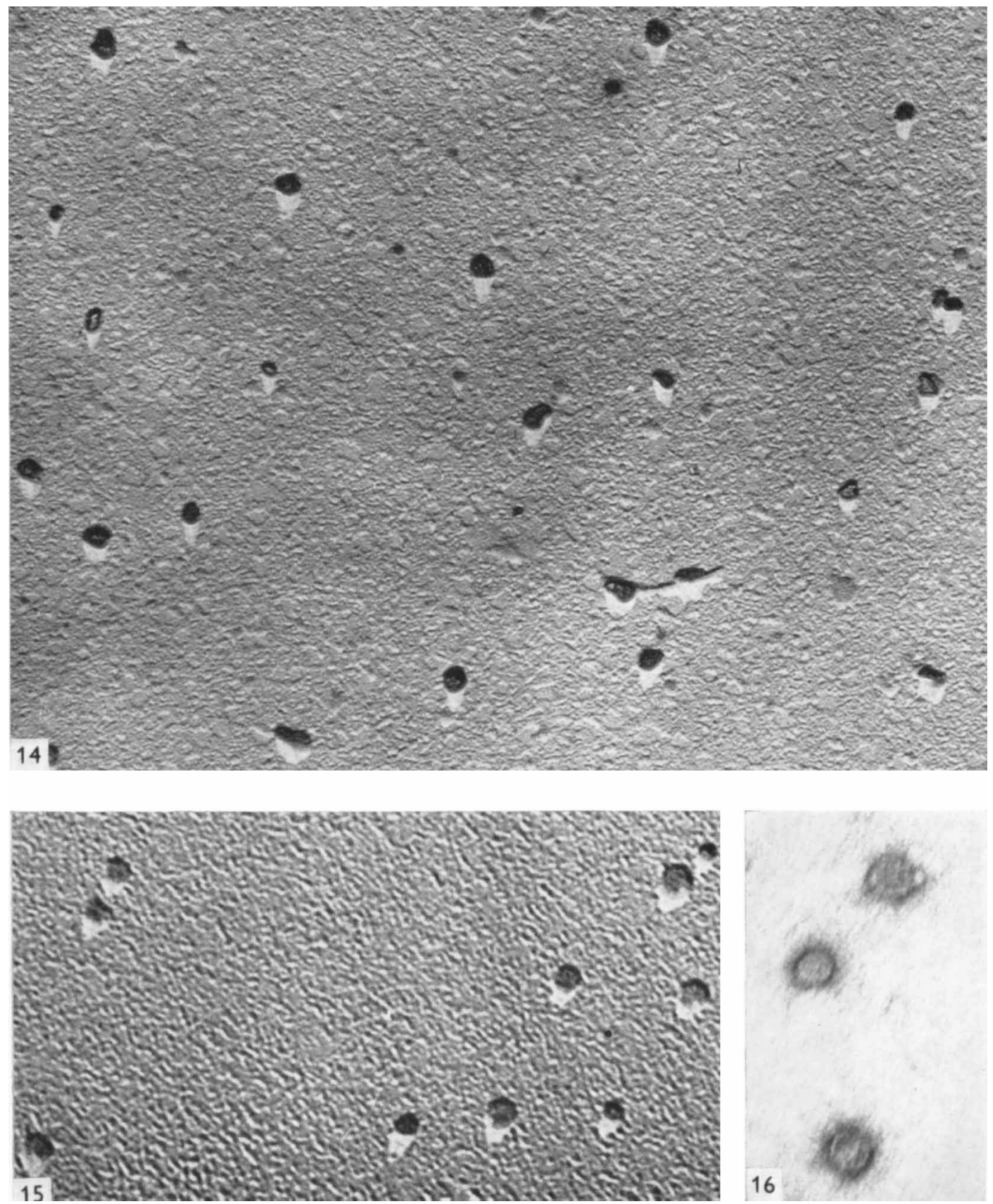
Plate 3

Fig. 6. A dividing cell stained with potassium permanganate. Sac-like structures (SS) formed by the bulged out cell-wall portion are presumably ready to be pinched off. $\times 48,000$.

Fig. 7. Part of fig. 6 at a higher magnification. The granules $\left(G^{\prime}\right)$ in association with the sac-like structure (SS) are distinctly seen. Many apparently similar granules (G) are seen in the bacterial cytoplasm. $\times 96,000$.

Fig. 8. Cross-section of a cell harvested from a logarithmic phase culture in peptone water and stained with potassium permanganate. Many granules have taken up considerable stain. The granules are associated with fibrillar structures present in the cytoplasm. $\times 50,000$.

Fig. 9. Oblique section of another cell harvested during the logarithmic phase of growth and stained with potassium permanganate. Fibrillar structures in the protoplasm and the associated granules can be seen. $\times 50,000$.

Fig. 10. $V$. cholerae cell harvested during the logarithmic phase of growth in Syncase medium and stained with potassium permanganate. Arrows indicate the fibrillar structures which have possibly originated by infolding of plasma membrane. Sac-like structure (SS) formed by the bulging out of cell wall is presumably ready to be pinched off. An apparently pinched off sac-like structure (SS) can also be seen. $\times 81,000$.

\section{Plate 4}

Fig. 11. $V$. cholerae cell harvested from a logarithmic phase culture in Syncase medium with bulges (A, B) on the cell wall. Sections of apparently pinched off sac-like structures (SS) are also seen. Stained with lead. $\times 75,000$.

Fig. 12. $V$. cholerae cell undergoing plasmolysis. The protoplast has retracted from the cell wall. Note that the cell-wall structure is smooth. Stained with lead. $\times 70,000$.

Fig. 13. Cross-section of $V$. cholerae cell harvested after $1.5 \mathrm{hr}$ incubation in glucose saline solution. Cell wall bulging and the formation of sac-like structures (SS) can be seen in several places (arrow). Stained with lead. $\times 87,000$.

\section{Plate 5}

Fig. 14. Particles isolated from the bacteria-free filtrate of the glucose saline solution in which the vibrios harvested from an $18 \mathrm{hr}$ agar culture were incubated for $4-6 \mathrm{hr}$. Shadowed with chromium. $\times 60,000$.

Fig. 1 5. Chromium-shadowed particles isolated from a logarithmic phase culture of vibrios in Syncase medium. $\times 60,000$.

Fig. 16. Particles isolated from a log-phase peptone water culture and negatively stained by uranyl acetate. $\times 100,000$ 